\title{
FUEL PROPERTY INVESTIGATION OF DIESEL AND MUSTARD OIL BIODIESEL MIXTURES AT DIFFERENT RATIOS
}

\author{
Fatih AYDIN ${ }^{* 1}$ Hidayet OĞUZ ${ }^{2}$ Hüseyin ÖĞÜT ${ }^{3}$ \\ 1. Selçuk University, Technical Science College, 42130 Konya / Turkey \\ 2. Necmettin Erbakan University, Faculty of Engineering and Architecture, 42060 Konya / Turkey \\ 3. Selçuk University, Faculty of Agriculture, 42130 Konya / Turkey
}

\begin{abstract}
Searching for alternative energy resources in order to compensate energy need in the world is continuing. One of the fuel types among alternative fuels is biodiesel fuel that can be used directly in diesel engines without any necessity for major modifications in the engine; that is environment friendly and renewable; that comprises similar fuel properties to diesel fuel. In this study, wild mustard oil methyl ester production was realized via transesterification method by using the oil extracted from wild mustard seed. Obtained biodiesel coded as B100 was mixed with diesel fuel at $2 \%, 5 \%, 10 \%$ and $20 \%$ volumetric ratios and obtained mixture fuels were coded as B2, B5, B10 and B20 respectively. Fuel properties of the mixture fuels were examined.

Consequently, it was recognized that the biodiesel produced from wild mustard oil is convenient for fuel standards except for its viscosity.
\end{abstract}

Keywords: Wild mustard oil, biodiesel, oil crop, transesterification.

\section{INTRODUCTION}

Energy as an indispensable part of human life, takes part among the debated subjects in world agenda as it did in the past. Energy is continuing to be an essential factor for economical and social development of countries and thus its also a foctor for improvement of social welfare [11].

Having an important place for human and animal feeding, crops with oily seeds also draw attention as an important raw material for the industry and energy fields [13].

To achieve this goal, wild mustard is one of the investigated oil plants. Absence of nutrient qualification of wild mustard oil plays an important role for the conversion of oil extracted from it to fuel.

Wild mustard (Sinapis arvensis L.) (Cruciferae) grows among crops as a wild herb. It is also cultivated in the third world countries and it is known as the origin of black mustard [1].

Mustard is an annual herbaceous plant at $0.2-1.5 \mathrm{~m}$ heights with white or yellow flowers. There are nearly ten species of it. Most of them grow in countries next to Mediterranean Sea.
Mustard has different species which are white mustard herb, black mustard herb and wild mustard. Its body height is $20-80 \mathrm{~cm}$, corolla width is about $50 \mathrm{~cm}$. Body has circular cross section, upright position, bottom surface without hairs. The plant is usually hairy, sometimes bald, an annual plant. Leaves are in alternating order, oval, no lobes and with coarse serration. Lower leaves sometimes can be simple and irregularly serrated, higher leaves have short stem or without stem and serrated[11].

Wild mustard plant is seen in Figure 1.
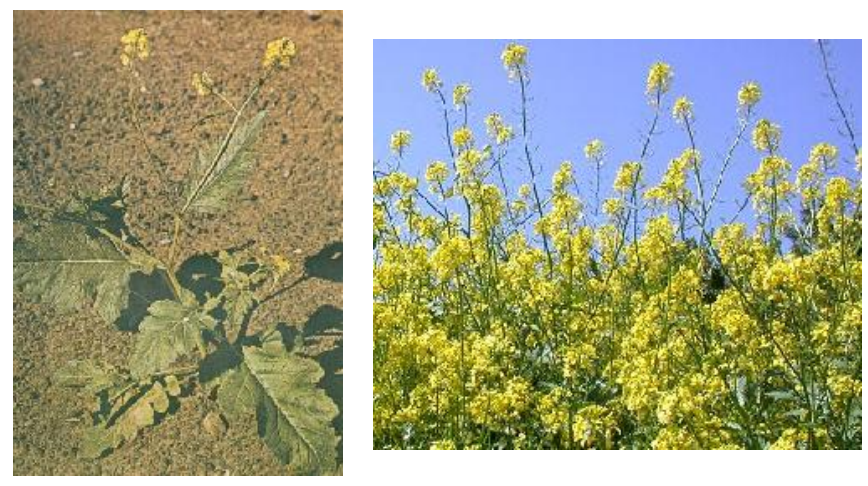

Fig.1 Wild mustard [4]

\section{MATERIAL AND METHODS}

The production of the biodiesel from wild mustard oil used as the material in the study was realized in the Biodiesel Laboratory located in Selcuk University Agriculture Faculty Agriculture Machinery Department.

Methyl alcohol was used as alcohol, $\mathrm{NaOH}$ was used as catalyst and transesterification was used as production method during biodiesel production [5].

Properties of produced wild mustard biodiesel were examined in the Biodiesel Examination Laboratory in Selcuk University Agriculture Faculty Agriculture Machinery Department. Properties of analyzed biodiesel are given in Table 1. 
TABLE 1. Analyses results of the fuels

\begin{tabular}{|c|c|c|c|c|c|c|c|c|c|c|c|}
\hline \multirow{3}{*}{$\begin{array}{c}\begin{array}{c}\text { Characteristic } \\
\text { Properties }\end{array} \\
\text { Density }\left(15^{\circ} \mathrm{C}\right)\end{array}$} & \multirow{3}{*}{$\begin{array}{l}\text { Units } \\
\mathrm{g} / \mathrm{cm}^{3}\end{array}$} & \multirow{3}{*}{$\begin{array}{r}\text { Diesel } \\
0,843\end{array}$} & \multirow{3}{*}{$\begin{array}{l}\text { B100 } \\
0,888\end{array}$} & \multirow{3}{*}{$\begin{array}{c}\text { B2 } \\
0,843\end{array}$} & \multirow{3}{*}{$\begin{array}{c}\text { B5 } \\
0,845\end{array}$} & \multirow{3}{*}{$\begin{array}{r}\mathbf{B 1 0} \\
0,847\end{array}$} & \multirow{3}{*}{$\begin{array}{c}\mathbf{B 2 0} \\
0,851\end{array}$} & \multicolumn{4}{|c|}{ Limiting Values } \\
\hline & & & & & & & & \multicolumn{2}{|c|}{ Biodiesel } & \multicolumn{2}{|c|}{ Diesel } \\
\hline & & & & & & & & 0,86 & 0,90 & 0,82 & 0,84 \\
\hline $\begin{array}{c}\text { Kinematic } \\
\text { Viscosity }\left(40^{\circ} \mathrm{C}\right)\end{array}$ & $\mathrm{mm}^{2} / \mathrm{s}$ & 3 & 7,28 & 3,04 & 3,08 & 3,2 & 3,5 & 3,50 & 5,00 & 2 & 4,5 \\
\hline Calorific Value & $\mathrm{cal} / \mathrm{gr}$ & 10834 & 9513 & 10687 & 10619 & 10559 & 10469 & - & - & - & - \\
\hline CFPP & ${ }^{\circ} \mathrm{C}$ & -22 & 5 & $-20,8$ & -20 & -10 & -8 & - & - & - & - \\
\hline Water Content & $\mathrm{mg} / \mathrm{kg}$ & 44,503 & 499,15 & 49,516 & 51,503 & 71,059 & 136,96 & - & 500 & - & 200 \\
\hline $\begin{array}{l}\text { Copper Strip } \\
\text { Corrosion }\end{array}$ & ------- & $1 \mathrm{a}$ & $1 \mathrm{a}$ & $1 \mathrm{a}$ & $1 \mathrm{a}$ & $1 \mathrm{a}$ & $1 \mathrm{a}$ & - & No:1 & - & No: 1 \\
\hline
\end{tabular}

Density: Is one of the important parameters. Measurement is performed via a hydrometer. When high density is measured, it indicates that glycerol is not able to be removed sufficiently. Measurement temperature is stated as $15{ }^{\circ} \mathrm{C}$ in the related standard. At this temperature, density of the biodiesel should be around $860-900 \mathrm{~kg} / \mathrm{m}^{3}$ according to TS EN 14214. Experimental method is performed according to EN ISO 3675 and EN ISO 12185 [11].

Density values of obtained fuels are seen in Figure 2.

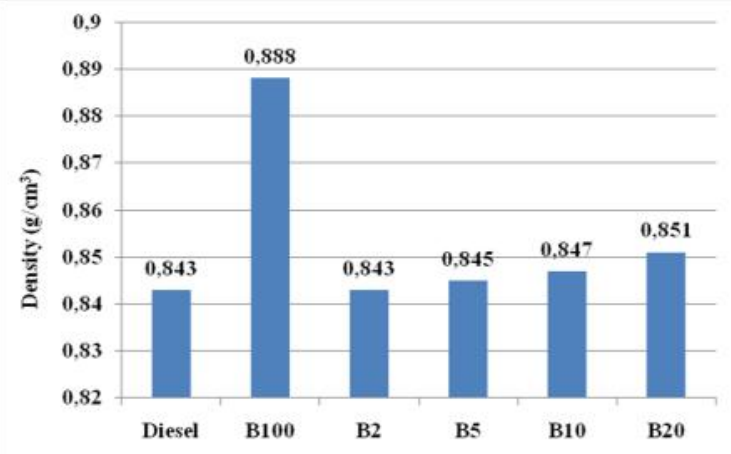

Fig. 2 Density values of the fuels

Kinematic Viscosity: Viscosity is the resistance that fluids exhibit against flow. Measurements are done with a viscometer. If the transesterification process couldn't be able to satisfactorily completed, viscosity would be measured high. This indicates that glycerol remains in the biodiesel. Glycerol is removed mostly during cleansing with water. Glycerol that couldn't be removed from the fuel causes viscosity to have higher values [9].

High values of viscosity start to cause blockage in the nozzles, continue with insufficient spraying, insufficient combustion, carbon accumulation on the piston rings, decrease in engine power and degradation of engine oil [10][12].

Viscosity value of biodiesel should be between 3.5 to 5 $\mathrm{mm} / \mathrm{s}$ at $40{ }^{\circ} \mathrm{C}$ according to TS EN 14214. Examination is conducted according to EN ISO 3104 . Kinematic viscosity values of the obtained fuels are seen in Figure 3.

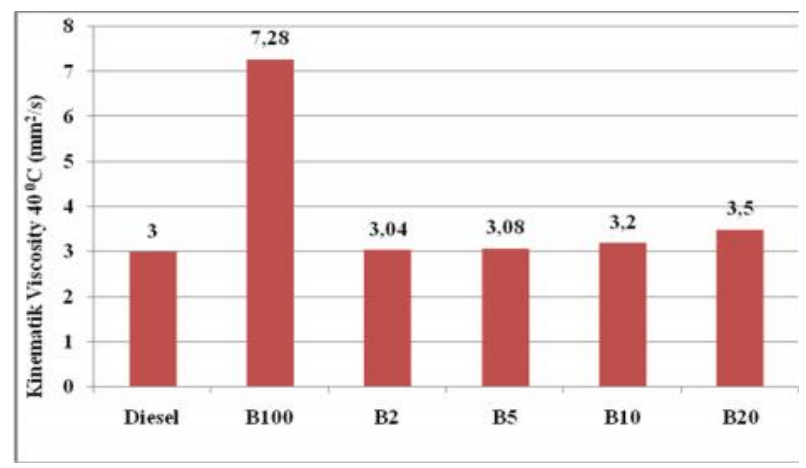

Fig. 3 Kinematic viscosity values of the fuels

Calorific Value: Utilization purpose of the fuels is to release energy for producing work. Calorific value is an indicator of energy amount that can be harnessed from fuels. Energy amount per unit volume of a fuel is defined as "Caloric Value" $\left(\mathrm{kcal} / \mathrm{m}^{3}\right)$ and energy amount per unit mass of a fuel is defined as Calorific Value of the fuels $(\mathrm{kcal} / \mathrm{kg})$. Heat values of the fuels are measured by means of combustion of the fuels in a calorimeter bomb[6][7][8].

Caloric values of the obtained fuels are seen in Figure 4.

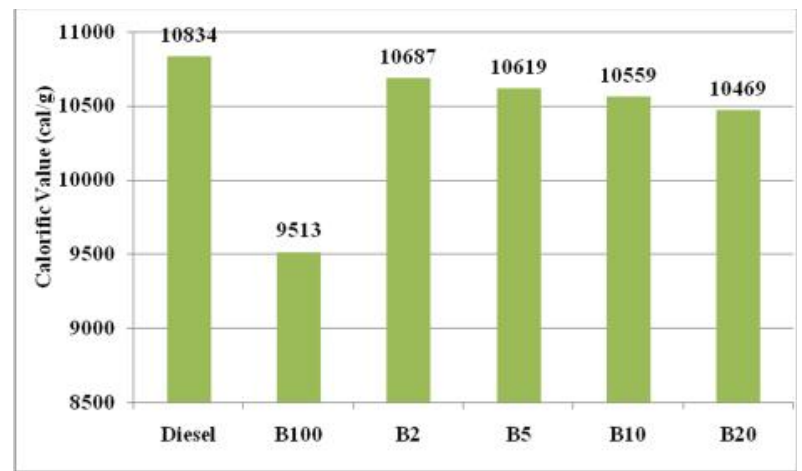

Fig. 4 Caloric values of the fuels 
Cold Filter Plunge Point (CFPP): It defines the temperature level at which a $20 \mathrm{~mL}$ sample can safely pass through the filter in a 60 second period and it is the point that wax crystals that occur at cloud point gather together in case of a temperature drop. In that case, the filter is blocked. CFPP characterizes cold weather characteristics of diesel engine fuel better than cloud point. As one of the properties mentioned here, CFPP takes place in TS EN 14213 and 14214 [2][3].

Cold filter plunge point of the obtained fuels are seen in Figure 5 .

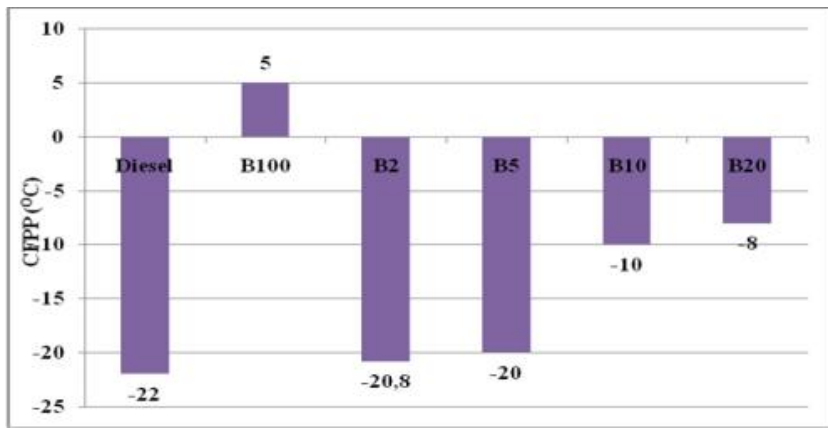

Fig. 5 Cold filter plunge point of the fuels

Water Content: Water content of the biodiesel is determined by this test. Water content above the stated limit mentioned in the standard cause oxidation and bacterial growth during storage, usage and it affects cold weather characteristics. Such a case would lead to acidification of the biodiesel and cause mud occurrence [9][10].

Especially cleansing and drying processes in the production method of the biodiesel are very important in respect of water content in the final product, drying must be done decently. Water content determination is practiced by means of Karl Fischer Coulometric Titration Method. Water content of biodiesel must be maximum $500 \mathrm{mg} / \mathrm{kg}$ according to TS EN 14214. Examination procedure is according to EN ISO 12937 [11].

Water content values of the obtained fuels are seen in Figure 6.

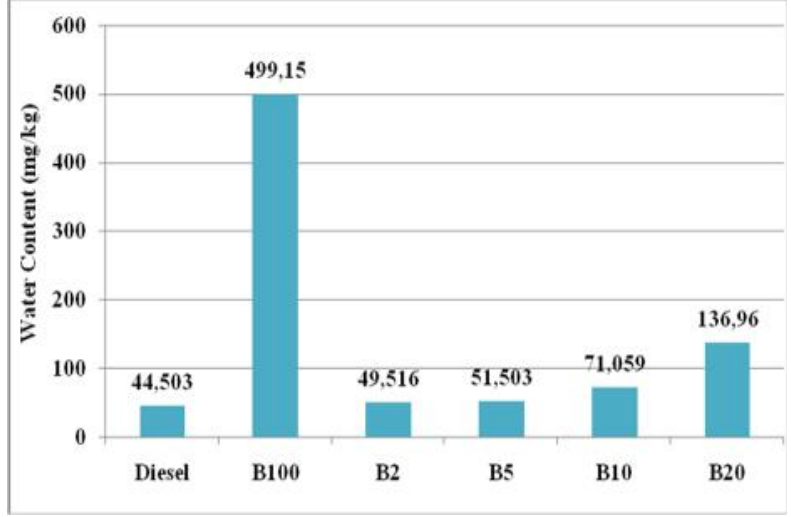

Fig. 6 Water content values of the fuels
Copper Strip Corrosion: This test exhibits the property of the fuel to corrode bronze, brass and copper materials in the fuel system. Sulphur, water and acid compounds in the biodiesel constitution causes darkening (change of color) over copper strip and this is an indicator of corrosion. During copper strip corrosion test, a cleaned copper strip is submerged into biodiesel fuel and held at that position while the temperature is $50^{\circ} \mathrm{C}$ for three hours and corrosion degree is determined after the strip is compared with copper strip test scale. Copper strip corrosion value of the biodiesel fuel must be maximum class 1 according to TS EN 14214. Testing is practiced according to EN ISO 2160 [11].

In our analyses, copper strip corrosion value was found to be class 1a for all fuels.

\section{CONCLUSIONS}

It can be said that industrial utilization of wild mustard oil is favorable because of limitation for its utilization as human food.

When the results of the examinations are investigated, maximum values for density, kinematic viscosity and water content were measured for B100 fuel as $0.888 \mathrm{~g} / \mathrm{cm}^{3}, 7.28$ $\mathrm{mm}^{2} / \mathrm{s}$ and $499.15 \mathrm{mg} / \mathrm{kg}$ respectively. Also minimum caloric value was measured for B100 fuel as $9513 \mathrm{cal} / \mathrm{g}$. Cold Filter Plunge Point was measured as $+5{ }^{\circ} \mathrm{C}$ for B 100 fuel and copper strip corrosion test yielded class 1a result for all fuels.

In the light of these results, Density, Caloric Value, Cold Filter Plunge Point (CFPP), Water Content and Copper Strip Corrosion values of different mixtures of wild mustard biodiesel fuel and diesel fuel are proper in respect of TS EN 14214 standard. In the other hand, kinematic viscosity value of B100 fuel is above the limits of the standard. In order to overcome this problem, fuel mixtures can be used rather than B100 fuel.

As the conclusion, wild mustard has the biodiesel raw material qualification due to being an oil plant without affecting food safety.

\section{REFERENCES}

[1] Akgül, A., 1993, Spices Science and Technology, Food Technology Association, Publication No.:15. Ankara.

[2] Anonymous, 2005, TS EN 14213. Heating Fuels-Fatty Acid Methyl Esters (FAME), Requirements and Test Methods, Ankara.

[3] Anonymous, 2009, TS EN 14214. Automotive Fuels-Fatty Acid Methyl Ester (FAME / Biodiesel) Specifications and Test Methods for Diesel Engines, Ankara.

[4] Anonymous, 2014, [online], http://www.ciceksehri.com/yabanihardal-sinapis-arvensis-1/, Date of Visit: [08.07.2014].

[5] Aydin, F., 2014, Effects of using e-b diesel fuel in single cylinder diesel engine to engine performance, Emissions And Lubrication Oil, Ph.D. thesis, The Graduate School Of Natural And Applied Science Of Selcuk University, Konya.

[6] Aydoğan, H., 2011, Investigation Of Engine Performance And Exhaust Emission Effect Using Bioethanol-Diesel Fuel Blends (EDiesel), Ph.D. thesis, The Graduate School Of Natural And Applied Science Of Selcuk University, Konya.

[7] Çengel, Y., A. ve Boles, M., A., 2008, With Thermodynamics An Engineering Approach, Fifth Edition, zmir Güven Kitabevi, 946. 
[8] Çolak, A. 2006. The Effect Of Ethanol Usage On Performance And Emissions At Various Compression Ratios In Spark Ignition Engine, Master Thesis, The Graduate School Of Natural And Applied Science Of Karaelmas University, Zonguldak, 70.

[9] Demir, C. 2006. Biodiesel Standards and Methods of Analysis, Journal of World Biofuels. Number:1 p 48-49, Ankara.

[10] Erol, A., Kemanoğlu, F., Ay, M.A., Uysal, B.Z. 2006. Comparison of Biodiesel Derived from Different Oil, Energy Crops and Green Fuels Symposium on 14-15 December 2006, Ege University Faculty of Agriculture, zmir.

[11] Eryllmaz, T., 2009, The Effect Of The Different Mustard Oil Biodiesel Blending Ratios On Diesel Engines Performance, Ph.D. thesis, The Graduate School Of Natural And Applied Science Of Selcuk University, Konya.
[12] Oğuz, H. 2004, The Investigation Of The Possibilities Of Using Hazelnut Oil Biodiesel As Fuel In Diesel Engines Which Use Widespread On Agriculture Sector, Ph.D. thesis, The Graduate School Of Natural And Applied Science Of Selcuk University, Konya.

[13] Öğüt, H., Oğuz, H., Şahin, S., Aydın, F., Uygun, S., Arslan,Y., ve Subaş1,., 2014, Investigation of Biodiesel Pelemir of Technical Specifications, Energy Agriculture and Biofuels 4th National Workshop 28-29 May 2014, Samsun 